\title{
Niespecyficzne metody wykorzystywane w terapii szumów usznych - przegląd wybranych technik
}

\section{Non-specific methods in tinnitus therapy - a review of selected techniques}

\author{
Rafał Milner ${ }^{1}$, Monika Lewandowska², Małgorzata Ganc ${ }^{1}$ \\ ${ }^{1}$ Instytut Fizjologii i Patologii Słuchu, Światowe Centrum Słuchu, Zakład Audiologii Eksperymentalnej, \\ Warszawa/Kajetany \\ ${ }^{2}$ Instytut Fizjologii i Patologii Słuchu, Światowe Centrum Słuchu, Naukowe Centrum Obrazowania \\ Biomedycznego, Warszawa/Kajetany
}

Adres autora: Rafał Milner, Światowe Centrum Słuchu, Zakład Audiologii Eksperymentalnej, ul. Mokra 17, Kajetany, 05-830 Nadarzyn, e-mail: r.milner@ifps.org.pl

\begin{abstract}
Streszczenie
Szumy uszne to złożone (nie tylko słuchowe) zaburzenie, któremu bardzo często towarzyszą problemy natury poznawczo-emocjonalnej. Pomimo iż szumy stanowią coraz większy problem społeczny, wciąż nie do końca poznany jest mechanizm ich powstawania. Ze względu na złożoną naturę zaburzenia nadal nie ma standardów diagnostycznych oraz w pełni skutecznych metod terapii szumów usznych. Niniejsza praca prezentuje przegląd wybranych niespecyficznych technik stosowanych w leczeniu szumów usznych, takich jak: techniki wykorzystujące zjawisko habituacji, terapia poznawczo-behawioralna (ang. Cognitive Behavioral Therapy, CBT), metody relaksacyjne oraz techniki związane z neuromodulacją i zmianą aktywności neuronalnej, takie jak: przezczaszkowa stymulacja prądem stałym (ang. transcranial Direct Current Stimulation, tDCS), przezczaszkowa powtarzana stymulacja magnetyczna (ang. Transcranial Magnetic Stimulation, TMS) czy neurofeedback.
\end{abstract}

Słowa kluczowe: niespecyficzne metody terapii szumów usznych $\bullet$ habituacja $\bullet$ terapia poznawczo-behawioralna $\bullet$ metody relaksacyjne • przezczaszkowa stymulacja prądem stałym • przezczaszkowa stymulacja magnetyczna $\bullet$ neurofeedback

\begin{abstract}
Tinnitus is a complex (not only auditory) disorder, often coexisting with cognitive and emotional problems. Although tinnitus is becoming an increasing social problem, the mechanisms of this disorder is still not fully understood. Because of a complex nature of the tinnitus, diagnostic standards and fully effective methods of its treatment have been not developed yet. This paper presents an overview of selected non-specific methods applied in the tinnitus treatment, i.e. habituation, cognitive-behavioral therapy, relaxation, as well as techniques based on neuromodulation and changing of abnormal neuronal activity such as the transcranial Direct Current Stimulation (tDCS), Transcranial Magnetic Stimulation (TMS) or neurofeedback.
\end{abstract}

Key words: non-specific methods of tinnitus treatment $\bullet$ habituation $\bullet$ cognitive-behavioral therapy $\bullet$ relaxation methods • transcranial direct current stimulation $\bullet$ transcranial magnetic stimulation $\bullet$ neurofeedback

\section{Wstęp}

Szumy uszne - (ang. tinnitus) to wrażenia słuchowe słyszane bez obecności zewnętrznego źródła dźwięku i powodujące dyskomfort u osoby, która ich doświadcza. Mogą one przyjmować postać różnych dźwięków, jak na przykład dzwonienie, pisk, gwizd, szum, brzęczenie, odgłos cykania świerszczy, pukanie lub inne dowolne kombinacje. Szumy uszne mogą być słyszalne w jednym uchu lub obojgu uszach, czasami są też opisywane jako dźwięk występujący np. w środku głowy. Zaburzenia te bardzo często współwystępują z różnego rodzaju innymi dysfunkcjami słuchowymi, takimi jak niedosłuch czy nadwrażliwość słuchowa [1,2]. Długo trwający nieustanny szum jest również przyczyną zaburzeń poznawczych czy emocjonalnych. Osoby z szumem usznym uskarżają się niejednokrotnie na problemy z koncentracją, wzmożone napięcie nerwowe, zaburzenia snu, bóle głowy, nadmierny stres, zaburzenia lękowe czy depresję [3,6].

Dane epidemiologiczne pokazują, że szumy uszne to zaburzenie, które stanowi poważny problem społeczny. Według Narodowego Centrum Statystyki Medycznej Amerykańskiego Ministerstwa Zdrowia, Edukacji i Opieki Społecznej ok. 30\% populacji osób dorosłych w Stanach 
Zjednoczonych doświadcza tych dolegliwości. $6 \% \mathrm{z}$ tych osób (czyli 1,8\% całej populacji) wskazuje, iż szumy uszne w istotny sposób wpływają niekorzystnie na ich życie [5]. $\mathrm{Z}$ innych badań przeprowadzonych w różnych krajach Europy (jak: Wielka Brytania, Szwecja czy Norwegia) wynika z kolei, że częstość występowania szumów usznych w populacji tych państw waha się od $4,4 \%$ do $15,5 \%$ [6]. Okazuje się również, że odsetek osób cierpiących na szumy uszne w Polsce jest podobny. Dane z badań przeprowadzonych przez Instytut Fizjologii i Patologii Słuchu (IFPS) w Warszawie pokazują, że w naszym kraju na szumy trwające dłużej niż 5 minut uskarża się około $20 \%$ populacji osób dorosłych. Na obecność stale doświadczanych szumów wskazuje natomiast około 5\% Polaków [7]. Szacuje się również, że w naszym kraju co dziesiąta osoba między 55 a 64 rż. i co piąta po 75 rż. cierpi na szumy uszne [8].

Pomimo iż szumy uszne są poważnym zaburzeniem (jak pokazują powyżej przedstawione dane), jak dotąd nie ma jednej spójnej teorii opisującej mechanizm i miejsce ich powstawania. Przez wiele lat uważano, że miejscem, w którym zachodzą patologiczne procesy wywołujące szumy uszne, jest wyłącznie ucho [9]. Dopiero Jurgen Tonndorf, naukowiec niemiecki, obserwując podobieństwo szumów usznych w wielu aspektach do chorób, w których dominują tzw. dolegliwości fantomowe, jako pierwszy sformułował model neurofizjologiczny, wskazujący, że przyczyną szumów usznych nie są dysfunkcje wyłącznie na poziomie ucha, lecz także ośrodkowego układu nerwowego [10]. Od momentu powstania modelu Tonndorfa przedstawiono wiele innych hipotez opisujących etiologię szumów usznych (patrz np. [11-13]). W przeważającej większości są one zbieżne $z$ hipotezą Tondorfa i wskazują, że większość szumów usznych spowodowana jest przez nieprawidłową aktywność neuronalną w systemie nerwowym, która jest skutkiem braku dopływu informacji do mózgu z receptora słuchu [9]. Przyczyn, z powodu których dochodzi do tej deprywacji, może być wiele, począwszy od tak trywialnych jak zatkanie ucha woskowiną po bardziej poważne, wywołane uszkodzeniem organicznym w obrębie ucha wewnętrznego spowodowanym np. urazem akustycznym, infekcją bakteryjną lub wirusową, ototoksycznym działaniem leków czy też zaburzeniami mikrokrążenia w obrębie ślimaka. Szumy uszne może powodować też nieprawidłowy rozrost kości w obrębie ucha, choroby takie jak: nadciśnienie tętnicze, choroba Meniere’a, w której dysfunkcji ulega błędnik połączony ze ślimakiem ucha wewnętrznego, różnego rodzaju nowotwory głowy i szyi, zwłaszcza nerwów czaszkowych, zaburzenia krążenia, choroby metaboliczne i inne. Uważa się, że wszystkie te czynniki mogą zaburzać lub wpływać na przewodzenie impulsów nerwowych z ucha do ośrodków słuchowych w korze mózgu, generując niepożądaną aktywność w ośrodkowym układzie nerwowym, odbieraną jako szum [9].

\section{Niespecyficzne metody terapii szumów usznych}

Złożona natura szumów usznych oraz nie do końca poznany mechanizm ich generacji powodują, iż zaburzenia te stanowią również istotny problem diagnostyczny. Nadal brakuje także jednej w pełni skuteczniej metody leczenia tych dolegliwości. W praktyce klinicznej mamy obecnie wiele różnych metod terapii szumów. Jeśli przyczyna, która je powoduje, jest dobrze uchwytna, stosuje się z reguły odpowiednią interwencję medyczną (farmakologię, zabieg chirurgiczny lub inne tradycyjne metody) i szumy zazwyczaj ustępują. W większości przypadków jednakże nie jest możliwe precyzyjne zidentyfikowanie przyczyny powstania szumów. W takich sytuacjach bardzo często sięga się po różnego rodzaju niespecyficzne metody terapii.

\section{Metody terapii szumów usznych wykorzystujące zjawisko habituacji}

Większość z nich ma na celu spowodować jak najszybszą habituację szumu usznego, czyli taki stan, w którym bez jakiegokolwiek świadomego wysiłku jesteśmy w stanie go ignorować. Aby osiągnąć stan habituacji, stosuje się między innymi metody oparte na różnego rodzaju stymulacjach akustycznych. Mają one na celu przede wszystkim przyśpieszyć proces habituacji poprzez wzmożenie aktywności neuronalnej w prawidłowo funkcjonujących drogach nerwowych $\mathrm{z}$ ucha od ośrodków słuchowych, a tym samym zmniejszyć kontrast pomiędzy ciszą a szumem usznym, czyniąc go trudniejszym do zauważenia. Wśród metod terapii opartych na stymulacji akustycznej wyróżnić możemy na przykład metody: 1) wykorzystujące tzw. maskowanie czy też 2) oparte na aktywnym słuchaniu.

Metody, które wchodzą w skład pierwszej grupy, wykorzystują z reguły generatory dźwięków wytwarzające szeroko- lub wąskopasmowy szum o częstotliwości zbliżonej do własnego szumu usznego, które mają na celu zastąpić (zamaskować) odbiór szumu innym dźwiękiem [14,15]. $\mathrm{W}$ najprostszym przypadku jako generator dźwięku stosowane mogą być różne urządzenia domowe, jak na przykład: wentylatory, komputery czy radioodbiorniki. W bardziej wyszukanych formach tego typu terapii słuchowej do maskowania stosuje się na przykład aparaty słuchowe. Mogą one służyć do protezowania słuchu i wzmocnienia odbieranych dźwięków, kiedy mamy do czynienia z szumem usznym i ubytkiem słuchu lub też jedynie do zwiększenia tła akustycznego, kiedy szum uszny występuje przy prawidłowej czułości słuchu, dzięki czemu odbiór szumu jest bardziej tłumiony. Przeprowadzone badania pokazują, iż wykorzystanie aparatów słuchowych jest bardzo skuteczną metodą terapii szumów usznych. Prawidłowo dopasowane aparaty są w stanie zmniejszyć stopień percepcji szumu usznego w ponad 60\% przypadków. Często jednak użycie aparatów słuchowych napotyka pewne ograniczenia. Znane są na przykład przypadki tzw. reaktywnego szumu, gdy głośniejsze dźwięki zewnętrzne zdają się intensyfikować percepcję szumu, może wystąpić też dyskomfort związany z fizycznym dopasowaniem lub noszeniem aparatu oraz wiele innych przeszkadzających czynników [16].

Innym rodzajem metod wykorzystujących stymulację akustyczną są metody oparte na aktywnym słuchaniu. Kluczowym elementem tego rodzaju terapii jest odwracanie uwagi od nieprzyjemnego bodźca. Aktywne słuchanie to proces, w którym osoba świadomie skupia swoją uwagę na konkretnym bodźcu dźwiękowym. Metody oparte na aktywnym słuchaniu w najprostszej formie polegają na przykład na słuchaniu ulubionej muzyki, angażującej uwagę słuchającego czy też słuchaniu dialogów radiowych lub oglądaniu interesujących audycji telewizyjnych [17]. W bardziej wyszukanej formie stosuje się specjalnie skonstruowane urządzenia, które odtwarzają muzykę wybraną przez pacjenta i specjalnie przystosowaną do jego oczekiwań i potrzeb [18]. 
Terapia poznawczo-behawioralna i techniki relaksacyjne

Jak wspomniano wcześniej, wystąpienie szumów usznych wiąże się bardzo często z pojawieniem się szeregu niepożądanych reakcji poznawczo-emocjonalnych. Szum pogarsza bowiem bardzo często zdolności koncentracji uwagi, wywołuje lęk, zwiększa stres i zmęczenie, bardzo często wpływa także niekorzystnie na sen osoby, która go doświadcza, powoduje obniżenie nastroju, a w skrajnych przypadkach depresję. Organizm jest w stanie ciągłej gotowości, układ nerwowy jest nadmiernie przeciążony i w efekcie wszystkie bodźce, a zwłaszcza te o podłożu negatywnym, są jeszcze silniej percypowane. Strach oraz negatywne reakcje, jakie wywołuje szum uszny, w oczywisty sposób utrudniają proces habituacji i są istotnym problemem dla pacjenta [14].

W terapii szumów usznych stosuje się więc coraz częściej różnego rodzaju niespecyficzne metody, które umożliwiają zmianę negatywnych nastawień pacjenta oraz zmodyfikowanie niewłaściwych reakcji behawioralnych [19]. Techniki te są często bardzo proste. W wielu przypadkach wystarczy po prostu zwykła konsultacja lekarska, aby zmienić nastawienie pacjenta i poprawić jego funkcjonowanie. Niekiedy jednak potrzebna jest dalsza terapia. Wśród niespecyficznych metod, które wydają się bardzo obiecujące, wymienia się najczęściej techniki wykorzystywane już od dawna np. w leczeniu chronicznego bólu. Okazuje się, że chroniczny ból i szumy uszne są dolegliwościami posiadającymi wiele podobieństw. Obie są zazwyczaj wrażeniami subiektywnymi, niewykrywalnymi i podlegającymi wpływom wydarzeń zewnętrznych [20,21]. Jednym z przykładów takiej terapii jest terapia poznawczo-behawioralna CBT (ang. Cognitive-Behavioral Therapy) [22,23]. W terapii tej dąży się do zmiany myślenia i zachowań przeszkadzających w procesie adaptacji poprzez systematyczne wdrażanie strategii mających na celu zastąpienie niepożądanych zachowań. Terapia CBT pomaga pacjentom zidentyfikować te myśli (część kognitywna) i zachowania (część behawioralna), które podtrzymują negatywne reakcje, następnie podsuwa strategie ich zmiany.

Innym rodzajem niespecyficznych technik, które korzystnie wpływają na sferę poznawczo-emocjonalną związaną z szumem usznym, są wszelkiego rodzaju techniki relaksacyjne. Ponieważ stres zmniejsza zdolność do radzenia sobie z niepożądanym objawem, jakim jest szum, często towarzyszy mu nadmierne napinanie mięśni. Wiadomo również, że na poziom odczuwanego szumu wpływ ma wiele czynników somatycznych, takich jak: zaciskanie szczęk, zgrzytanie zębami, nadmierne napięcie mięśni, zwłaszcza w odcinku szyjnym kręgosłupa. Wiele technik relaksacyjnych (np. joga, progresywny trening relaksacyjny, masaż), które powodują rozluźnienie różnych partii ciała i mięśni, znajduje więc zastosowanie w terapii osób z szumem usznym. Nauka redukcji napięcia mięśniowego pozwala też obniżyć poziom stresu, poprawia sen i tym samym korzystnie wpływa na subiektywną percepcję szumu [19].

W tym miejscu warto również wspomnieć o technice Mindfulness, zdobywającej coraz większą popularność w terapii różnego rodzaju zaburzeń, w tym szumów usznych. Jest to metoda, która wykorzystuje zarówno elementy terapii poznawczo-behawioralnej, jak i technik relaksacyjnych, dzięki czemu obszar jej oddziaływań jest o wiele bardziej uniwersalny. Mindfulness to szczególny rodzaj uwagi: świadomej, nieosądzającej i skierowanej na obecną chwilę [24]. Osoba uczestnicząca w treningach Mindfulness uczy się tzw. „całkowitej obecności” („uważności”) wobec doświadczeń płynących zarówno z zewnątrz (np. dostarczanych przez inne osoby), jak i z wewnątrz (własne myśli, uczucia, wrażenia) niezależnie od tego, jakie są w danej chwili. Celem jest rozwinięcie świadomości własnego ciała oraz wszelkich treści, które przechodzą do świadomości, i przyjęcie ich takimi, jakie są. Osoba z szumami usznymi, która praktykuje Mindfulness, uczy się także traktować w ten sam sposób doświadczany przez siebie szum. Istotą tej metody jest wypracowanie i przeniesienie do codziennego życia postawy całkowitej akceptacji rzeczy takimi, jakie są, w tym również nieprzyjemnego bodźca, jakim jest szum [25].

\section{Tinnitus Retraining Therapy}

Opisując różne metody wykorzystywane w terapii szumów, należy wspomnieć o opracowanej przez profesora Jastreboffa metodzie TRT (ang. Tinnitus Retraining Therapy). Metoda ta od wielu lat jest ceniona przez specjalistów zajmujących się tematyką szumów usznych. Dzieje się tak dlatego, iż jako jedna z nielicznych ma udowodnioną empirycznie skuteczność [11]. Olbrzymią zaletą metody TRT jest to, iż łączy w sobie elementy zarówno technik poznawczo-behawioralnych, jak i technik przyśpieszających habituację. Do zapoczątkowania tego procesu wykorzystuje się elementy stymulacji słuchowej. W terapii TRT jest ona $\mathrm{z}$ reguły realizowana za pomocą generatora szumu szerokopasmowego, który zakłada się na uszy lub ucho. Specyfika tej metody polega na tym, że szum $z$ generatora, zwłaszcza w początkowej fazie terapii, ma być ustawiony tak, aby nie maskował całkowicie szumu pacjenta, lecz raczej łączył się z nim tak, aby oba sygnały były słyszalne, a żaden $\mathrm{z}$ nich nie był uciążliwy. W miarę postępu w terapii poziom szumu generatora zmniejsza się stopniowo i dostosowuje do coraz słabszego szumu pacjenta. Według Jastreboffa w ten sposób niejako „oszukujemy” mózg. „Słysząc” słabiej sztucznie zagłuszany (maskowany) niepożądany sygnał własny, powodujemy, że układ limbiczny, który odpowiada za emocje, jest mniej aktywowany. W efekcie sygnał ten staje się coraz mniej istotny i kierowana jest na niego coraz mniejsza uwaga, a z czasem jego percepcja przestaje być uświadamiana. W terapii TRT oprócz stymulacji słuchowej bardzo ważne są konsultacje lekarskie i psychologiczne, które pacjent odbywa regularnie. Spełniają one tę samą rolę co w terapii CBT - mają na celu zmniejszyć negatywną odpowiedź poznawczo-behawioralno-emocjonalną na odczuwany szum uszny [14].

\section{Metody terapii wpływające na zmianę aktywności neuronalnej w mózgu}

Jak wspomniano wcześniej, większość teorii dotyczących etiologii szumów usznych wskazuje, iż spowodowane są one zmienioną aktywnością neuronalną w ośrodkowym układzie nerwowym, powstałą pod wpływem braku dopływu informacji z receptora słuchu (ucha) [26]. Hipotezę tę potwierdzają liczne badania eksperymentalne, w których u osób z szumem usznym obserwowano na przykład: zmiany w częstości wyładowań neuronów lub cyklicznej bioelektrycznej aktywności mózgu, zachodzące zarówno 
w ośrodkach korowych, jak i w drogach nerwowych łączących ośrodki korowe i podkorowe [27-29], zmienioną synchronizację i koherencję neuronów w korze słuchowej [30] czy też zmiany w organizacji tonotopowej [31]. Co również bardzo istotne, zmiany te nie są ograniczone wyłącznie do pewnych specyficznych obszarów np. kory słuchowej, lecz wydają się dotyczyć złożonych sieci łączących różne struktury i obszary mózgowe, zarówno korowe jak i podkorowe, jak również związane albo niezwiązane z przetwarzaniem słuchowym [32-34]. Wśród niespecyficznych metod leczenia szumów usznych w ostatnich latach coraz bardziej popularne stają się więc techniki, które służyć mają znormalizowaniu zaburzonej aktywności neuronalnej, mającej miejsce w złożonych sieciach struktur mózgowych.

\section{Przezczaszkowa stymulacja prądem stałym i przezczaszkowa powtarzana stymulacja magnetyczna}

Do metod tych zaliczają się na przykład: przezczaszkowa stymulacja prądem stałym (ang. transcranial Direct Current Stimulation, tDCS) oraz przezczaszkowa stymulacja magnetyczna (ang. Transcranial Magnetic Stimulation, TMS). Pierwsza z technik polega na stymulacji mózgu pacjenta poprzez umieszczone na jego głowie specjalne (z reguły dwie) elektrody transmitujące (przewodzące) przez korę mózgową prąd stały o niewielkim natężeniu $(0,5-2 \mathrm{~mA})$. W drugiej $\mathrm{z}$ metod zamiast prądu do stymulacji używane jest zmieniające się szybko pole magnetyczne. Specjalnie izolowana i rozmieszczona nad powierzchnią głowy pacjenta cewka dostarcza krótkotrwałe, wysokiej intensywności impulsy elektryczne. Impulsy te indukują pole magnetyczne, którego linie przebiegają prostopadle do linii pola elektrycznego i które łatwo penetruje czaszkę oraz mózg osoby poddawanej terapii. Celem obu metod jest lokalna zmiana i normalizacja aktywności spontanicznej neuronów w stymulowanych obszarach kory mózgowej. U pacjentów z szumem usznym są to $\mathrm{z}$ reguły obszary, które tworzą tzw. sieć tinnitusa (ang. tinnitus network), czyli grupę struktur i rejonów mózgowych zaangażowanych w generację szumu [35,36].

\section{Neurofeedback}

Inną niespecyficzną metodą, z którą wiąże się olbrzymie nadzieje co do zastosowania w terapii szumów usznych, jest metoda neurofeedback. Podstawą działania tej techniki jest wykorzystanie zjawiska tzw. biologicznego sprzężenia zwrotnego (ang. biofeedback) oraz mechanizmów uczenia się opartych na warunkowaniu instrumentalnym [37]. Jak udowodniono wiele lat temu, warunkowaniu takiemu podlegać mogą różne sygnały/parametry odzwierciedlające działanie różnych układów organizmu (jak np. ciśnienie krwi, temperatura ciała czy tempo oddychania), w tym również sygnał bioelektryczny mózgu (czyli sygnał EEG) [38]. W trakcie terapii neurofeedback jest on rejestrowany z głowy pacjenta za pomocą specjalnych czujników (sensorów). Z sygnału tego obliczane są różnego rodzaju parametry opisujące stan czy też funkcjonowanie mózgu, np. moc fal mózgowych o różnych częstotliwościach. Wielokrotnie udowodniono, że ekspresja fal o określonych częstotliwościach zmienia się w zależności od stanu mentalnego, w jakim się znajdujemy. Moc sygnałów w poszczególnych pasmach (fal) i różnych rejonach mózgu jest również inna w różnego rodzaju chorobach i dysfunkcjach pracy mózgu.
Nieprawidłowa ekspresja spoczynkowej aktywności bioelektrycznej mózgu była też wielokrotnie obserwowana u pacjentów z szumami usznymi $[28,33,39,40]$. Wykorzystując tzw. ilościową analizę sygnału EEG - QEEG (ang. quantitative electroencephalography) [41], wykazano, że $\mathrm{w}$ porównaniu $\mathrm{z}$ osobami zdrowymi osoby te mają nieprawidłowo zawyżoną ekspresją fal w paśmie delta (1-4 Hz). U osób z szumem obserwowano również zaniżoną ekspresją fal w paśmie alfa $(8-12 \mathrm{~Hz})$ oraz nadmiernie podwyższony tzw. współczynnik delta/alfa, odzwierciedlający wzajemne relacje fal alfa i delta mających zaburzoną ekspresję. Badania wykazały również istnienie istotnych korelacji pomiędzy wartością współczynnika D/A, obliczanego z sygnałów rejestrowanych w prawej korze skroniowej oraz lewej korze czołowej, a subiektywnym stopniem nasilenia szumu usznego. W innych badaniach przeprowadzonych u osób z szumami usznymi wykazano też nieprawidłową ekspresję bardzo szybkich (o wysokiej częstotliwości) fal z zakresu beta czy gamma. Tego typu efekt był obserwowany przede wszystkim również w rejonach skroniowych mózgu [28].

Istotą treningów neurofeedback u pacjentów z szumem jest normalizacja opisanych powyżej nieprawidłowych aktywności. Jest to możliwe, gdyż osoba uczestnicząca w tego rodzaju treningu w czasie realnym otrzymuje informację o zmieniających się parametrach związanych $\mathrm{z}$ wybranymi pasmami fal mózgowych. Ponieważ parametry te są często bardzo złożone i mogłyby być niezrozumiałe dla osoby trenującej, informacja o ich stanie przekazywana jest najczęściej w atrakcyjnej formie audiowizualnej (np. pod postacią gry lub planszy wideo). Jeśli trenowany parametr osiągnie wcześniej zdefiniowany poziom, trenujący otrzymuje nagrodę, którą może być określone „zachowanie” gry, sygnał dźwiękowy lub inna forma gratyfikacji. Dzięki temu jego mózg „niejako wie, w którą stronę należy podążać”. Jak wspomniano wcześniej, generacja poszczególnych zakresów fal mózgowych wiąże się z określonym stanem umysłu. Osoba trenująca, wprowadzając się w określony stan mentalny, modyfikuje więc i wpływa na związane z nim aktywności mózgowe [37].

Jako standard w terapii szumów usznych z wykorzystaniem metody neurofeedback stosuje się obecnie tak zwany protokół delta/alfa. Ma on na celu znormalizowanie nieprawidłowej ekspresji zakresów fal delta oraz alfa, których stosunek opisuje i które u osób z szumami usznymi są zmienione. Okazje się, że skuteczność tego rodzaju protokołu jest bardzo duża. Została ona również potwierdzona empirycznie. Wyniki badań przeprowadzonych na grupie osób z szumem usznym, u których stosowano trening neurofeedback oparty na protokole $\mathrm{D} / \mathrm{A}$, pokazują bowiem, że osoby, którym udaje się zmodyfikować jednocześnie zarówno czynność alfa jak i delta, doświadczają znaczącej redukcji szumów usznych [42].

\section{Neurofeedback z wykorzystaniem wolnych potencjałów korowych - wyniki własne}

W terapii neurofeedback sygnałem, który wykorzystuje się do biologicznego sprzężenia zwrotnego, są też czasami tzw. wolne potencjały korowe (ang. Slow Cortical Potentials, SCP). SCP to trwające nawet kilka sekund odchylenia napięcia w sygnale EEG, przypominające zmiany prądu stałego. Częstotliwość tych potencjałów mieści się w zakresie poniżej $0,5 \mathrm{~Hz}$ [43]. W latach 70. i 80. XX w. grupa, której liderami byli Nils 
Birbaumer oraz Thomas Elbert - znani naukowcy niemieccy z Uniwersytetu w Tubingen, przeprowadziła szereg badań, na podstawie których stwierdzono, iż te wolne zmiany napięcia w sygnale EEG mają związek ze zmianami pobudliwości w korze mózgowej. Wykazano między innymi, że ujemne SCP związane są z aktywacją mózgu, obniżeniem progu pobudliwości neuronów w korze i przygotowaniem danego rejonu kory do wykonania specyficznego dla niego zadania. Dodatnie SCP związane są natomiast z podwyższeniem pobudliwości komórek nerwowych w korze mózgowej, a więc z silniejszą aktywacją mechanizmów hamowania w mózgu [44,45].

Wielokrotnie udowodniono, że nauka modyfikacji pracy mózgu za pomocą biologicznego sprzężenia zwrotnego zmiany wolnych potencjałów korowych ma korzystny wpływ na pacjentów $z$ różnego rodzaju problemami. Trening neurofeedback ujemnych SCP wykorzystywany był $\mathrm{z}$ powodzeniem $\mathrm{w}$ terapii osób na przykład po udarach mózgu czy osób z ADHD, czyli z zaburzeniami, w których stymulacja niedostatecznie zaktywowanej części kory mózgu jest jak najbardziej korzystna [46]. Z kolei dostępne badania i praktyka kliniczna pokazują, że trening SCP dodatnich potencjałów korowych bardzo dobrze sprawdza się w leczeniu np. epilepsji, migreny i innych dysfunkcji, w których zwiększenie mechanizmów hamowania w korze mózgowej jest bardzo pożądane $[47,48]$.

W Instytucie Fizjologii i Patologii Słuchu w ramach realizacji grantu Narodowego Centrum Nauki opracowano metodę terapii pacjentów $\mathrm{z}$ szumem usznym wykorzystującą neurofeedback wolnych potencjałów korowych (skrót: SCP Neurofeedback), której celem jest nauczenie osób doświadczających szumy uszne wprowadzania się w stan mentalny ściśle związany z generacją dodatnich wolnych potencjałów korowych. Jak pokazują badania, o których wcześniej wspomniano, percepcja szumu usznego związana jest $\mathrm{z}$ nieprawidłową aktywnością $\mathrm{w}$ różnych rejonach kory mózgowej (np. $[29,39,40])$. Niewykluczone więc, że generacja szumu usznego wynika z tego, że neurony w korze słuchowej, "broniąc się" przed zmniejszeniem ilości informacji dopływających $\mathrm{z}$ ucha wewnętrznego, robią się nadmiernie pobudliwe i zaczynają się nadmiernie synchronizować. To powoduje wrażenie szumu usznego.

Ideą protokołu opracowanego w IFPS jest wzmacnianie za pomocą SCP Neurofeedback mechanizmów hamowania w korze mózgowej, podwyższenie progu pobudliwości neuronów korowych poprzez naukę generowania dodatnich SCP. Zakłada się tym samym, że nadmierna aktywność w korze mózgowej związana z szumem powinna pod wpływem tego typu interwencji ulec zmniejszeniu lub też całkowitemu wytłumieniu.

Wyniki wstępne, które uzyskano w IFPS po zakończeniu terapii SCP Neurofeedback, wydają się bardzo obiecujące. U pacjentów, którzy zakończyli cały cykl terapii, obserwowano korzystny wpływ treningów zarówno na subiektywne odczuwanie szumu usznego, jak i różne aspekty codziennego funkcjonowania. Na podstawie wyników behawioralnych testów charakterystyki szumu u pacjentów poddanych terapii stwierdzono także obniżenie natężenia oraz zmianę częstotliwości percypowanego sztucznie dźwięku. Korzystne zmiany widoczne były nie tylko w testach behawioralnych, lecz miały także odzwierciedlenie w wynikach badania ilościowego EEG - QEEG. Po zakończeniu terapii obniżeniu uległa ekspresja fal związanych z generacją szumów usznych z zakresu delta, alfa oraz beta. Efekty te były widoczne w obszarach uważanych za kluczowe w generacji szumów usznych [49].

\section{Podsumowanie}

Przedstawiony w niniejszej pracy przegląd metod pokazuje, że obecnie istnieje wiele niespecyficznych technik stosowanych w terapii chronicznych szumów usznych. Są wśród nich metody, których celem - poprzez różnego rodzaju stymulacje słuchowe - jest głównie jak najszybsza habituacja doświadczanego szumu usznego. Inne metody mają za zadanie przede wszystkim zmianę negatywnego nastawienia do bodźca odbieranego jako nieprzyjemny. W ostatnich latach coraz większą popularność zyskują metody wpływające bezpośrednio na aktywność neuronalną mózgu, która - jak pokazują liczne badania - jest znacznie zmieniona u pacjentów z szumami usznymi. Wydaje się, że najlepsze efekty może przynieść konstruktywne łączenie, w zależności od potrzeb, różnego rodzaju technik terapeutycznych.

\section{Podziękowania}

Badania własne, które przedstawiono w pracy, sfinansowano ze środków grantu Narodowego Centrum Nauki nr 2011/03/D/NZ4/02431.

\section{Piśmiennictwo:}

1. Skarżyński H. Szumy uszne i nadwrażliwość na dźwięki. Warszawa: Instytut Fizjologii i Patologii Słuchu; 1998.

2. Bartnik G. Szumy uszne i nadwrażliwość słuchowa. Warszawa: Instytut Fizjologii i Patologii Słuchu; 2010.

3. Landgrebe M, Langguth $B$. Tinnitus and psychiatric co-morbidity. W: Møller AR, Langguth B, DeRidder D, Kleinjung T, red. Textbook of Tinnitus. New York: Springer; 2011, 491-2.

4. Crönlein T, Geisler P, Hajak G. Tinnitus and sleep. W: Møller AR, Langguth B, DeRidder D, Kleinjung T, red. Textbook of Tinnitus, New York: Springer; 2011, 505-10.

5. Heller AJ. Classification and epidemiology of tinnitus. Otolaryngol Clin North Am, 2003; 36: 239-48.
6. Hoffman HJ, Reed GW, George W. Epidemiology of tinnitus. $\mathrm{W}$ : Snow JB, red. Tinnitus theory and management. PMPH: USA; 2004, 16-41.

7. Skarżyński H. Szumy uszne w życiu codziennym. Porady praktyczne dla pacjentów. Warszawa: Instytut Fizjologii i Patologii Słuchu; 2000.

8. Fabijańska A. Badania epidemiologiczne szumów usznych i nadwrażliwości słuchowej na świecie i w Polsce. W: Skarżyński H, red. Szumy uszne i nadwrażliwość na dźwięki. Warszawa: Instytut Fizjologii i Patologii Słuchu; 1998, 35-41.

9. Møller AR. Pathology of the auditory system that can cause tinnitus. W: Møller AR, Langguth B, DeRidder D, Kleinjung T, red. Textbook of Tinnitus. New York: Springer; 2011, 77-93. 
10. Tonndorf J. The analogy between tinnitus and pain: a suggestion for a physiological basis of chronic tinnitus. Hear Res, 1987; 28: 271-5.

11. Jastreboff PJ. Tinnitus retraining therapy. W: Langguth GH, Kleinjung T, Cacace A, Møller AR, red. Progress Brain Research. Amsterdam: Elsevier; 2007, 166, 415-23.

12. Schlee W, Lorenz I, Hartmann T, Müller N, Schulz H, Weisz N. A global brain model of tinnitus. W: Møller AR, Langguth B, DeRidder D, Kleinjung T, red. Textbook of Tinnitus. New York: Springer; 2011, 161-9.

13. De Ridder D. A heuristic pathophysiological model of tinnitus. W: Møller AR, Langguth B, DeRidder D, Kleinjung T, red. Textbook of Tinnitus, New York: Springer; 2011, 171-97.

14. Jastreboff PJ. Tinnitus Retaining Therapy: An implementation of the neurophysicological model of tinnitus. Cambridge University Press; 2004.

15. Watanabe K, Kamio T, Ohkawara D, Aoki H, Baba S, Yagi T. Suppression of tinnitus by band noise masker - a study of 600 cases. Nihon Jibiinkoka Gakkai Kaiho, 1997; 100: 920-5.

16. Del Bo L, Ambrosetti U. Hearing aids for the treatment of tinnitus. W: Langguth GH, Kleinjung T, Cacace A, Møller AR, red. Progress Brain Research, Amsterdam: Elsevier; 2007, 166, 341-5.

17. Del Bo L, Baracca G, Forti S, Norena A. Sound stimulation. W: Møller AR, Langguth B, DeRidder D, Kleinjung T, red. Textbook of Tinnitus. New York: Springer; 2011, 597-604.

18. Távora-Vieira D, Davis PB. Rehabilitation of tinnitus patients using the Neuromonics tinnitus treatment. W: Møller AR, Langguth B, DeRidder D, Kleinjung T, red. Textbook of Tinnitus. New York: Springer; 2011, 605-12.

19. Greimel KV, Kröner-Herwig B. Tinnitus from the perspective of the psychologist. W: Møller AR, Langguth B, DeRidder D, Kleinjung T, red. Textbook of Tinnitus. New York: Springer; 2011, 223-8.

20. Moller AR. Similarities between severe tinnitus and chronic pain. J Am Acad Audiol, 2000; 11: 115.

21. Møller AR. Tinnitus and pain. W: Langguth GH, Kleinjung T, Cacace A, Møller AR, red. Progress Brain Research. Amsterdam: Elsevier; 2007; 166: 47-53.

22. Andersson G. Psychological aspects of tinnitus and the application of cognitive - behavioral therapy. Clin Psychol Rev, 2002; 22: 977-90.

23. Martinez Devesa P, Waddell A, Perera R, Theodoulou M. Cognitive behavioural therapy for tinnitus. Cochrane Database Syst Rev, 2007; (9):CD005233

24. Kabat-Zinn J, Hanh TN. Full catastrophe living: Using the wisdom of your body and mind to face stress, pain, and illness. New York: Bantam Dell a Division of Random House; 2009.

25. Gans JJ, O’Sullivan P, Bircheff V. Mindfulness based tinnitus stress reduction pilot study. Mindfulness, 2013; 1-12.

26. Møller AR. Pathology of the auditory system that can cause tinnitus. W: Møller AR, Langguth B, DeRidder D, Kleinjung T, red. Textbook of Tinnitus. New York: Springer; 2011, 77-93.

27. Llinás RR, Ribary U, Jeanmonod D, Kronberg E, Mitra PP. Thalamocortical dysrhythmia: a neurological and neuropsychiatric syndrome characterized by magnetoencephalography. Proc Natl Acad Sci, 1999; 96: 15222-7.

28. Weisz N, Müller S, Schlee W, Dohrmann K, Hartmann T, Elbert $\mathrm{T}$. The neural code of auditory phantom perception. J Neurosci, 2007; 27: 1479-84.
29. Van Der Loo E, Gais S, Congedo M, Vanneste S, Plazier M, Menovsky T i wsp. Tinnitus intensity dependent gamma oscillations of the contralateral auditory cortex. PLoS One, 2009; 4: e7396.

30. Eggermont JJ. Central tinnitus. Auris Nasus Larynx, 2003; 30: $7-12$.

31. Mühlnickel W, Elbert T, Taub E, Flor H. Reorganization of auditory cortex in tinnitus. Proc Natl Acad Sci, 1998; 95: 10340-3.

32. Schlee W, Weisz N, Bertrand O, Hartmann T, Elbert T. Using auditory steady state responses to outline the functional connectivity in the tinnitus brain. PLoS One, 2008; 3: e3720.

33. Schlee W, Hartmann T, Langguth B, Weisz N. Abnormal resting-state cortical coupling in chronic tinnitus. BMC Neurosci, 2009; 10: 11.

34. Schlee W, Mueller N, Hartmann T, Keil J, Lorenz I, Weisz N. Mapping cortical hubs in tinnitus. BMC Biol, 2009; 7: 80.

35. Vanneste $S$, De Ridder D. Transcranial direct current stimulation (tDCS): a new tool for the treatment of tinnitus? W: Møller AR, Langguth B, DeRidder D, Kleinjung T, red. Textbook of Tinnitus. New York: Springer; 2011, 711-5.

36. Eichhammer P, Kleinjung T, Landgrebe M, Hajak G, Langguth B. TMS for treatment of chronic tinnitus - neurobiological effects. Prog Brain Res, 2007; 166: 369-75.

37. Hartmann T, Lorenz I, Weisz N. Neurobiofeedback. W: Møller AR, Langguth B, DeRidder D, Kleinjung T, red. Textbook of Tinnitus. New York: Springer; 2011; 691-6.

38. Schwartz MS, Andrasik FE. Biofeedback: A practitioner's guide. New York: Guilford Press; 2003.

39. Weisz N, Moratti S, Meinzer M, Dohrmann K, Elbert T. Tinnitus perception and distress is related to abnormal spontaneous brain activity as measured by magnetoencephalography. PLoS Med, 2005; 2: e153.

40. De Ridder D, van der Loo E, Vanneste S, Gais S, Plazier M, Kovacs $S$ i wsp. Theta-gamma dysrhythmia and auditory phantom perception: Case report. J Neurosurg, 2011; 114: 912-21.

41. Kaiser DA. What is quantitative EEG? J Neurother, 2007; 10: 37-52.

42. Dohrmann K, Weisz N, Schlee W, Hartmann T, Elbert T. Neurofeedback for treating tinnitus. Prog Brain Res, 2007; 166: 473-554.

43. Strehl U. Slow cortical potentials neurofeedback. J Neurother, 2009; 13: 117-26.

44. Birbaumer N, Elbert T, Canavan AG, Rockstroh B. Slow potentials of the cerebral cortex and behavior. Physiol Rev, 1990; 70: $1-41$.

45. Birbaumer N. Slow cortical potentials: Plasticity, operant control, and behavioral effects. The Neuroscientist, 1999; 5: 74-8.

46. Strehl U, Leins U, Goth G, Klinger C, Hinterberger T, Birbaumer N. Self-regulation of slow cortical potentials: a new treatment for children with attention-deficit/hyperactivity disorder. Pediatrics, 2006; 118: e1530-40.

47. Siniatchkin M, Hierundar A, Kropp P, Kuhnert R, Gerber W-D, Stephani U. Self-regulation of slow cortical potentials in children with migraine: an exploratory study. Appl Psychophysiol Biofeedback, 2000; 25: 13-32.

48. Kotchoubey B, Strehl U, Uhlmann C, Holzapfel S, König M, Fröscher W i wsp. Modification of slow cortical potentials in patients with refractory epilepsy: a controlled outcome study. Epilepsia, 2001; 42: 406-16.

49. Milner R, Lewandowska M, Ganc M, Cieśla K, Niedziałek I, Jędrzejczak WW i wsp. Neurofeedback wolnych potencjałów korowych w terapii chronicznych szumów usznych. Praca nieopublikowana. 